10. Salamon S. M. Endophthalmitis after strabismus surgery / S. M. Salamon, T. R. Frieberg, M. N. Luxenberg // Am. J. Ophthalmol. - 1982. - Vol. 93(1). - P.39-41.
11. Schein O. D. Panophthalmitis after penetrating keratoplasty / O. D. Schein, J. W. Miller, M. D. Wagener // Arch. Ophthalmol. - 1989. - Vol. 107(1). - P. 21.

Поступила 22.06.2011. Рецензент ст. н. с., к. М. н. С. И. Полякова

\title{
EXPERIMENTAL MODEL OF BACTERIAL ENDOPHTHALMITIS
}

A. V. Zborovskaya, T. B. Kustrin, I. O. Nasinnyk

Odessa, Ukraine

The study was developed bacterial endophthalmitis modified model in experiments on rabbits.

\section{Обзор литературы}

УДК $615.36(048.8)$

\section{ПРЕПАРАТЫ ТКАНЕВОЙ ТЕРАПИИ. ЧАСТЬ 2. НАИБОЛЕЕ ШИРОКО ПРИМЕНЯЮЩИЕСЯ ПРЕДСТАВИТЕЛИ}

\author{
Н. В. Пасечникова, проф., Э. В. Мальцев, проф., \\ Е. П. Сотникова, проф, О. А. Мороз, канд. мед. наук
}

гу «Институт глазных болезней и тканевой терапии им. В. П. Филатова НАМН Украины».

Как и было оговорено в предыдущей части работы, в настоящем сообщении обсуждаются далеко не все из предложенных тканевых препаратов, а лишь только те из них, которые прошли проверку временем или же разработаны относительно недавно.

Алоэ. Конечно, не все из перечисленных средств одинаково широко применялись или применяются. Но несомненно, что одним из лидеров является экстракт алоэ, причем это касается как его применения в офтальмологии, так и в медицине в целом. Как следует из работ Л. Е. Черикчи, 1956 и инструктивно-методических материалов «Электрофорез лекарственных веществ при глазных заболеваниях», 1961, электрофорез экстракта алоэ лучше проводить с катода по 20-25 процедур на курс и его с успехом применяют при лечении герпетического, розацеа, паренхиматозного кератита, исходов туберкулезного и скрофулезного кератитов, с рассасывающей целью при помутнениях роговицы и как метод, стимулирующий зрительные функции - при миопическом хориоретините, пигментной дегенерации сетчатки, атрофии зрительного нерва. В основе механизма действия экстракта алоэ при таких заболеваниях глубоких отделов глаза лежит оживление функциональных свойств сохранившихся нервных элементов сетчатки и зрительного нерва. Широкое применение находит электрофорез экстракта алоэ при лечении послеоперационных и посттравматических осложнений (иридоциклит с кровоизлиянием в стекловидное тело, переднюю камеру, травматическая катаракта и пр.). При этом наблюдается прекращение воспалительных явлений, рассасывание крови, хрусталиковых масс. При нейрогенных кератитах уже после первых процедур у больных прекращаются либо значительно уменьшаются боли в глазу, сокращается продолжительность воспалительного периода, ускоряется рассасывание инфильтратов в роговице и эпителизация эрозий. У многих больных после курса электрофореза с экстрактом алоэ рассасывались помутнения роговицы давностью в 10-20 лет. Показан электрофорез алоэ и при кровоизлияниях в переднюю камеру, помутнениях после травмы и увета. Л. С. Терентьева (1956) получила положительные результаты от применения подкожных инъекций экстракта алоэ ежедневно, 30-45 процедур на курс при лечении симпатической офтальмии, а А. А. Ватченко и др. (1983) - от инстилляций экстракта алоэ и его электрофореза при весенне-летнем катаре.

Несколько позднее этот перечень был дополнен такими показаниями к электрофорезу алоэ (Черикчи Л. Е., 1966, 1971) как возможность рассасывания хрусталиковых масс, в том числе вязких, остаю-

(C) Н. В. Пасечникова, Э. В. Мальцев, Е. П. Сотникова, О. А. Мороз, 2011 
щихся после экстракции зонулярной катаракты, и даже для полного рассасывания травмированного хрусталика. При гипотонии на глазу с факотоксическим увеитом больным показан диатермоэлектрофорез с этим средством. Экстракт алоэ полезен и при старых кровоизлияниях в переднюю камеру и стекловидное тело в случае травматического увеита. При электрофорезе медикамент из ванночки проникает в глаз через роговицу, распространяясь далее по сосудистой оболочке, а в хрусталике - его больше всего в передних наружных и экваториальных слоях, а менее всего в задних наружных и ядерных слоях. Электрофорез из ванночки в различные ткани и среды глаза позволяет ввести столько же лекарственного средства, что и подконъюнктивальные его инъекции и гораздо больше по сравнению с внутримышечными, подкожными и ретробульбарными инъекциями (Черикчи Л. Е., 1988). Автор последней работы предлагает расширить показания к применению экстракта алоэ (разумеется, как и обычно в случаях применения тканевой терапии, в сочетании с другими различными средствами, в том числе и вводимыми путем электрофореза) также и для лечения травматического увеита с набухающей травматической катарактой. В этом случае электрофорез экстракта алоэ можно проводить два, а у детей при хорошей переносимости лечения и три раза в день. При этом общее количество сеансов рассасывающей терапии может быть доведено до 60 и более. В случае лечения травматического увеита с гемофтальмом, гифемой, опять же в составе комплексной терапии, проводится электрофорез алоэ или его электрофорез в смеси с гепарином по 25 сеансов на курс. Д. Ф. Ивановым и др. (1998) для лечения помутнений роговицы был разработан лазеро-магнитофорез алоэ (или торфота), что способствовало восстановлению ее прозрачности и уменьшению васкуляризации.

В методическом письме Л. Е. Черикчи (1968) сообщает о проведении физиотерапии глазных заболеваний у детей. Что касается применения алоэ в этом случае, то рекомендуется использовать его введение путем электрофореза для лечения герпетического кератита, нейрогенного, нейропаралитического, паренхиматозного, люэтического кератита, опять же сочетая с другими воздействиями и препаратами. Среди прочих рекомендуемых показаний называются гнойные язвы роговицы, гипопион, кератит, необходимость рассасывания пленок вторичной катаракты и травматической катаракты, а также кровоизлияний в стекловидном теле. Положительный результат приносит электрофорез алоэ при атрофии зрительного нерва, пигментной дегенерации сетчатки, миопическом хориоретините. Под влиянием биологически активных веществ (БАВ) восстанавливается нервная рецепция в той части элементов сетчатки и зрительного нерва, ко- торая под воздействием патологического процесса пребывает в состоянии функциональной заторможенности (парабиоза). Клинически это проявляется расширением границ поля зрения, уменьшением скотом, повышением остроты зрения. У детей с пигментной дегенерацией сетчатки улучшалось сумеречное зрение. А по данным И. Г. Дурас и др., (2003) курс тканевой терапии с использованием экстракта алоэ показан и пациентам с ранней сенильной макулодистрофией и постувеальными хориоретинальными дистрофиями с высокими зрительными функциями. То же самое можно сказать и относительно полезности экстракта алоэ для улучшения зрительных функций при проведении комплексной терапии тапеторетинальных абиотрофий сетчатки в практике детского офтальмолога. В этом случае отмечается повышение остроты зрения и расширение границ поля зрения при сохранении длительности эффекта в течение 3-12 месяцев (Лобачевская О. И., 2003). О положительном эффекте применения у больных диабетической ретинопатией препарата алоэ перед лазеркоагуляцией сетчатки сообщили Л. А. Сухина и др., (1998), а О. И. Тарасикова, Т. Н. Антонюк, (1983) такой же эффект отметили у 264 пациентов с эндогенными увеитами, получавшими электрофорез или фонофорез экстракта алоэ и торфот под конъюнктиву в ходе комплексной терапии.

Противовоспалительное и ранозаживляющее свойства сухого экстракта алоэ были использованы Б. М. Коганом и др., (2005), Г. И. Дрожжиной и др., (2009) в составе комплексной глазной мази (другие ее компоненты декаметоксин, витамины С и А) при лечении сухого кератоконъюнктивита. Положительный эффект был на седьмые сутки лечения у 92,3-96,2 \% больных нитчатым кератитом и глубоким ксерозом роговой оболочки, в то время как традиционное лечение (желе солкосерила) аналогичный результат дало только у $67 \%$ пациентов. Ранее сухой экстракт алоэ был с успехом применен в составе другой комплексной глазной мази, содержавшей кроме того лаферон, диоксидин, витамин С при герпетическом кератите (Гайдамака Т. Б. и др., 1999). У 96 \% пациентов с этим заболеванием отмечалась быстрая регрессия воспалительного процесca, ускорение эпителизации роговицы, повышение остроты зрения, отсутствие местнораздражающего действия и аллергических реакций. Предварительные эксперименты на кроликах показали, что эта мазь ускоряет регрессию воспалительного процесса при герпетическом кератоконъюнктивите и улучшает регенерацию роговицы. А другая группа исследователей (Сотникова Е. П. и др., 2003) в экспериментах на кроликах показала, что экстракт алоэ и в виде глазных капель оказывает стимулирующее действие на репаративные процессы в роговице, ускоряя заживление ее эпителиальной раны в 2,5 раза. 
Существенную роль при лечении приобретенной прогрессирующей миопии у детей и подростков играют таблетки алоэ, которые назначаются пациентам 2 раза в день за 15-30 минут до еды. Продолжительность курса лечения 4 недели, а интервал между повторными курсами 3-6 месяцев. Таблетки алоэ из сухих листьев растения содержат 3,16 \% органических и минеральных веществ, в том числе аминокислоты (аланин, аргинин, гистидин, изолейцин, лизин, серин, тирозин, треонин), углеводы (галактоза, глюкоза, сахароза, фруктоза), витамины $\mathrm{B}_{1}, \mathrm{~B}_{2}, \mathrm{~B}_{6}$, С и Р, ряд жирных кислот, а также более 20 микроэлементов (Пучковская Н. А. и др., 1986).

Препараты из торфа (торфот, пиридоксофот и гуминат.). Торф - неисчерпаемый источник биологически активных веществ, способных легко включаться в биохимические метаболические пути в организме человека и животных, а его действующие субстанции являются азотсодержащими (Solovieva V. P. et al., 1980). Гуминовые (мол. вес 10000-100000) и фульвовые (мол. вес 1000-30000) кислоты торфа биологически активны, благодаря тому что гуминовые субстанции образуют комплексы с биологически активными веществами, модифицируя их физиологическую активность. В то же время фульвовые кислоты связывают водонерастворимые высокомолекулярные компоненты, превращая их в водорастворимые (Szajdak L., MaryganovaV., 2005). Как сообщает Л. М. Степченко, 2003, Stepchenko L., 2000, 2010, биологически активные вещества гуминовой природы, содержащиеся в торфе, повышают адаптогенные возможности организма путем мобилизации всех звеньев функциональной системы, поддерживающей его гомеостаз и направленной на реализацию программ, связанных с уменьшением влияния повреждающего фактора. При этом в первую очередь затрагивается система гемопоэза, за счет которой может быть уменьшено состояние гипоксии и повышены защитные функции организма, в связи с чем наблюдается удлинение фазы адаптации генерализованного адаптационного синдрома по Селье.

В лаборатории фармакологии и тканевых препаратов Института им. Филатова разработаны три тканевых препарата из торфа: торфот (отгон торфа), пиридоксофот для инъекций, таблетки и глазные капли гумината (комплекс гуминовых кислот) (Solovieva V. et al., 1981, 1988, 1999). Производство торфота предусматривает извлечение из торфа только летучих соединений. Комплекс биологически активных гуминовых кислот оставался неиспользованным, пока не была предложена единая технологическая цепь изготовления двух препаратов: торфота и комплекса гуминовых кислот из одного и того же сырья с различным содержанием биологически активных веществ (Соловьева В. П. и др., 1982). Препараты относятся к группе неспец- ифических лекарственных средств, повышающих общую резистентность организма, но отличаются по химическому составу и особенностям фармакодинамики относительно биологической активности и лечебно-профилактического эффекта. Их объединяют выраженные антитоксические свойства, биорегулирующее воздействие на метаболические процессы организма, а также практическая безвредность: отсутствие аллергизирующих, тератогенных, эмбриотоксических и канцерогенных свойств. Все названные препараты апирогенны и повышают антитоксическую функцию печени. Они обладают антиоксидантными, антигипоксическими, мембраностабилизирующими свойствами, что обеспечивает широкий спектр их фармакологического действия, направленного на повышение неспецифической резистентности организма, а также способны оптимизировать лечебный эффект специфических медикаментозных средств, таких как антибиотики, сульфаниламиды, другие этиотропные препараты (Лотош Т. Д. и др., 2000, 2006, Сотникова Е. П. и др., 2008, Sotnikova Е. P. et al., 1988, Solovieva V. et al, 2000). По данным Т. Д. Лотош, (2003) к двадцатому дню введения кроликам гумината, торфота и пиридоксофота перекисная и осмотическая резистентность эритроцитов возрастала в 1,5-2 раза, а уровень белка в крови по сравнению с исходным фоном повышался на 7-10 \% за счет альбуминовой фракции.

Препарат торфот явлется продуктом отгонки торфа и содержит летучие биологически активные вещества - карбоновые кислоты, амины, фенолы (Лотош Т. Д., 1986) и интересен тем, что он не усугубляет состояние иммуносупрессии в период ее инициирования и не оказывает заметного иммунокорригирующего воздействия. Этим он отличается не только от белоксодержащих биорегуляторов (экстракты алоэ и плаценты), но и от другого также безбелкового тканевого препарата группы отгонов ФиБСа (Дегтяренко Т. В., 1995). Однако, наряду с последним и экстрактом плаценты, он восстанавливает содержание иммунокомпетентных клеток в тимусе. Это позволило автору заключить, что в клинической практике требуется дифференцированное применение тканевых препаратов с целью неспецифической иммуномодуляции, а также рекомендовать их применение после проведения курсов иммунодепрессивной терапии для достижения иммунореабилитации и иммунопрофилактики.

Торфот применяли и применяют в офтальмологической практике для лечения такой патологии глаза, как кератиты, атрофия зрительного нерва, диссеминированный хориоретинит, пигментный ретинит, миопия, скрофулез (Solovieva V. P. et al., 1976).

Торфот способен рассасывать вторичные помутнения роговицы при конъюнктивальном введении и фонофорезе, оптимизировать терапев- 
тическое действие антибиотиков при кератоконъюнктивитах (инстилляции), а также способствовать иммобилизации протеолитического фермента терилитина в глазных пленках. Предложены новая лекарственная форма - мазь на основе торфота, способная усиливать репаративные процессы роговицы (Абрамова Г. Б., Соколова Б. Н., 2006). По мнению Т. У. Горгиладзе, (1983), В. А. Суркова, В. Н. Семеновой, (1986) стимулирующее влияние торфота на обменные процессы в роговой оболочке способствует уменьшению интенсивности не только поверхностных ее помутнений, но и полезно при грубых васкуляризированных бельмах. А К. С. Титенко и др. (1986), применяя торфот, ФиБС, алоэ, пелоидодистиллят, стекловидное тело после экстракапсулярной экстракции катаракты, отметили лучший рассасывающий эффект остатков хрусталиковых масс именно у торфота.

А. А. Юмашева, Л. М. Рудзинский, (2003), используя через 1,5-3 месяца после травмы глаза парабульбарные и субконъюнктивальные инъекции торфота, у 98 больных получили более выраженное и быстрое рассасывание последствий кровоизлияний, рубцов и повышение зрительных функций. Несколько ранее Т. М. Шелінговська та ін., (1998) сообщили, что торфот при повреждении глаза и его последствиях способствует уменьшению посттравматической гипотонии, затуханию воспалительных явлений при рецидивах посттравматического увеита, рассасыванию хрусталиковых масс, заметному просветлению роговицы.

Р. М. Цок, Ю. М. Каминский, (1983) отметили несомненный терапевтический эффект субконъюнктивальных инъекций торфота при таких тяжелых сосудистых поражениях сетчатки, как диабетическая и гипертоническая ретинопатии, склеротическая макулодистрофия. А И. В. Бакаев, (2003) включил форез торфота, алоэ или ФиБСа на шейный отдел позвоночника в схему лечения с применением сосудорасширяющих, ноотропных и антиоксидантных средств у больных с центральной дистрофией сетчатки на фоне шейного остеохондроза. Результаты лечения у таких больных по показателям остроты и поля зрения, снижению порогов электрической чувствительности и повышению электрической лабильности оказались выше чем у лиц, у которых биостимуляторы не применялись. Автор не сообщает о сравнительных результатах лечения в зависимости от примененного тканевого препарата.

Равным образом Н. М. Абашина и др., (1998, 2003) не обнаружили разницы между лечебным воздействием торфота, алоэ, ФиБСа, пеллоидодистиллята и стекловидного тела, примененных для лечения различной патологии глаза (кератит, склерит, кератоконъюнктивит, увеит, хориоидит, хориоретинит и др.) при его туберкулезном поражении у 1330 пациентов. Однако они подчеркивают, что примене- ние тканевой терапии местно (путем электрофореза, парабульбарно, субконъюнктивально), а также общим путем в комплексном лечении на протяжении 3-4 недель приводило к повышению остроты зрения на $17 \%$, а поле зрения расширялось на $11 \%$. Кроме того, у пациентов количество осложнений снизилось на $20 \%$, улучшились показатели клеточного и гуморального иммунитета. Тем не менее, в более ранней из приведенных работ этих авторов алоэ назначалось при кератоувеитах нетуберкулезной этиологии, торфот - при туберкулезных кератоувеитах с преимущественным поражением роговицы, а ФиБС-при кератоувеитах с геморрагическими осложнениями. Торфот так же, как экстракты алоэ, плаценты либо ФиБС, стабилизирует прогрессирование близорукости и улучшает зрительные функции при ее высокой степени (Явтушенко В. Ф. и др., 1998). По данным Т. И. Давиденко и др., (2003), торфот со щелочной протеазой в глазных лекарственных пленках эффективен при лечении ожогов глаз, ускоряя ликвидацию признаков воспаления и эпителизацию роговицы. А Т. В. Баран и др., (1998) применяли торфот в комплексном лечении больных с изменениями при нарушениях кальциевого обмена в роговице и конъюнктиве у пациентов с терминальной почечной недостаточностью.

Пиридоксофот представлявляет собой соединение торфота с витамином $\mathrm{B}_{6}$. Он обладает антитоксическим действием, способностью повышать устойчивость организма к кислородному голоданию и замедлять процессы старения (Сотникова Е. П. и др., 1999). Как утверждают авторы указанной работы, этот препарат демонстрирует гепатопротекторное влияние и отчетливо предотвращает глиотоксическое действие тиолового яда - монобромацетата и ингибитора метаболизма-актиномицина Д. Как показали Б. Н. Соколова, Н. И. Шерина (2000), пиридоксофот при подкожном введении животным в дозе, превышающей терапевтическую в 50 раз, не обладает эмбриотоксическими и тератогенными свойствами. При введении пиридоксофота кроликам метаболические изменения в нейроглии зрительной зоны коры регистрируются даже раньше, чем в ее нейронах (Sotnikova E. P. et al., 1996).

При моделировании дистрофии сетчатки ингибитором гликолиза йодатом натрия оказалось, что предварительное введение пиридоксофота оказывает выраженный защитный эффект на сетчатку, обеспечивая в ней повышение содержания РНК, общего белка, тиолов в ганглиозных клетках и фоторецепторах, а также сохранение целостности слоя пигментного эпителия. Однако при моделировании пострадиационной дистрофии сетчатки его лечебнопрофилактические свойства оказались менее выраженными по сравнению с гуминатом (Молчанюк Н.И и др., 2003), хотя и обеспечивают протективное действие на структуры сетчатки и хориокапилля- 
ры (Sotnikova E. et al., 1999, 2000). Равным образом оказалось, что биологическая активность гумината более выражена и при сравнении его действия на клеточную культуру почек эмбриона человека с другим препаратом - мареполимиэлом, хотя оба они стимулировали митозы, уменьшали количество их патологических форм, гигантских клеток и симпластов (Салдан В. И., Гудзенко Т. В., 2003).

В. В. Савко и др., (2002), Т. В. Дегтяренко и др., (2003) использовали пиридоксофот в качестве иммуностимулятора для лечения 34 больных хроническим рецидивирующим увеитом на фоне противовоспалительной терапии. Было найдено, что применение пиридоксофота оказывало стимулирующее воздействие на Т-систему иммунитета, способствуя выраженному клиническому эффекту и предупреждению рецидивов заболевания. Такое лечение особенно показано больным с уменьшенным количеством Т-лимфоцитов в периферической крови.

Другим оригинальным отечественным лечебным средством, также получаемым из торфа, является гуминат или гумат натрия. Последний повышает антитоксическую функцию печени, стимулирует гемопоэз, ускоряет регенерацию (Lotosh T., Abramova A., 2000), причем его антитоксический эффект выше чем у пиридоксофота (Lotosh T., Zaporozchenko O., 1999). Механизм адаптационных и биорегулирующих свойств гумата натрия непосредственно связан со стимулирующим влиянием его на иммунологическую реактивность, антитоксическую функцию печени и с нормализацией сульфгидрильно-дисульфидного равновесия, а также показателей белкового и углеводного обмена (Solovjeva V. P. et al., 1985, Lotosh T. D. et al., 1988). Гуминат содержит в своем составе натриевую соль гуминовых кислот торфа, аминокислоты, микроэлементы и может применяться в виде таблеток, а также 0,1 и 1,0\% растворов в сочетании с 10 или 20 \% сульфацилом натрия (Салдан В. Й., 2008, 2010, Салдан В. Й., Сотнікова О. П., 2006, Saldan V. I., 2004, Sotnikova E. P. et al., 2005).

В последнем случае речь идет о глазных каплях, которые не оказывают цитотоксического действия, способствуют сохранению физиологической и повышению митотической активности культивируемых клеток монослоя без образования патологических митозов, что в условиях травматического кератита способствует ускорению эпителизации роговицы, затуханиюпризнаков воспаленияпереднего отдела глаза и прозрачному заживлению роговицы. При лечении бактериального кератита у животных инстилляции $20 \%$ раствора сульфацил-гумината оказывают выраженное противовоспалительное и регенераторное действие, что сопровождается ускорением процессов регенерации роговицы и выздоровления. При лечении бактериального кератита эти капли способствуют нормализации активности лизосомальных ферментов (кислая фосфатаза, катепсин Е), трансаминаз (аланин-аминотрансфераза и аспартат-аминотрансфераза ), трипсиноподобных протеиназ, окислительно -восстановительных процессов (лактатдегидрогеназа) в плазме крови и роговице кроликов. Полученные результаты имеют существенное значение в лечении травматических и бактериальных повреждений роговицы (кератиты, кератоконъюнктивиты). Тем более, что таблетки гумината регулируют метаболические и регенеративные процессы, стимулируют иммунореактивность организма и, по данным эксперимента, ослабляют действие иммунодепрессанта циклофосфана (Solovieva V. P. et al., 1996, Абрамова А. Б., Салдан В. И., 1998). Гуминат в таблетках целесообразно применять в комплексной терапии для лечения центральной дистрофии сетчатки (Савко В. В. и др., 1998), иных ее поражений (Sotnikova E., 2000), а другой препарат из торфа (торфот) - и при лечении дистрофии сетчатки и зрительного нерва у хронических алкоголиков (Скалыга И. М., 1998).

Как установлено экспериментальным путем В. И. Ивановым, Т. И. Сироштаненко, (2003), инстилляции $0,1 \%$ раствора гумината активируют симпатический отдел радужной оболочки, влияя тем самым на адаптивные реакции переднего отдела глаза.

Донник. Одним из вновь разработанных для тканевой терапии растительных препаратов является водный экстракт травы донника лекарственного, изготовленный по методу академика В. П. Филатова (Фесюнова Г. С., 2008). По фармакологическим свойствам и биорегулирующему действию он значительно превышает кумаринсодержащий тканевой препарат ФиБС. Сумма кумаринов, входящих в его состав, составляет 0,09 \% и представлена кумарином и двумя оксикумаринами (скополитином и умбиллифероном). Выявлен высокий уровень биологической активности экстракта донника. В зависимости от дозы $(0,2 ; 0,3 ; 0,5$ мл.) увеличивается продолжительность жизни и выживаемость лабораторных животных (на 11, 22, 36 \% соответственно). Курсовое введение экстракта донника повышает детоксикационную функцию печени: отмечено достоверное уменьшение продолжительности гексеналового сна на $20 \%$. Этот экстракт на 70-80 \% ингибирует агрегацию тромбоцитов крови человека, что в сравнении с контролем практически втрое выше (Карасева Н. А., 2003), чем у референспрепарата ФиБСа (27,5 \%). При 21-дневном введении кроликам экстракта донника установлены гипокоагулянтные свойства, которые характеризуются удлинением тромбинового, протромбинового, активированного парциального тромбопластинового времени, и активация фибринолитической системы. Это позволяет Е. П. Сотниковой и др., (2005) рекомендовать экстракт донника в качестве мягкого растительного гипокоагулянта в комплекс- 
ной терапии тромбозов разной локализации, в частности, в офтальмологии - при тромбозах ретинальных вен, макулодистрофии, диабетической ретинопатии, глаукоме.

Весьма существенно, что экстракт донника не обладает эмбриотоксическим действием и не оказывает отрицательного влияния на плодовитость и потомство подопытных животных в периоды имплантации, постимплантации и органогенеза (Сотникова Е. П. и др., 2006).

Как установлено Г. С. Фесюновой, С. Г. Коломийчук, (2007), курсовое введение экстракта донника способствует повышению уровня водорастворимых и жирорастворимых антиоксидантов в крови и увеличению активности каталазы в плазме и печени, а значит, и повышению антиоксидантного статуса организма. Одновременно проявляется и мембраностабилизирующее действие этого препарата, к тому же повышающего детоксикационную функцию печени (Сотнікова О. П., Фесюнова Г. С., 2006, Сотнікова О. П. та ін., 2006-б).

Ультраструктурные исследования клеток печени после 30-дневного введения экстракта донника выявили накопление количества рибосом, полисом, митохондрий, зернистой эндоплазматической сети, гликогена, что свидетельствует о его активирующем действии на белоксинтезирующую и энергообразующую функции, способствует повышению резистентности гепатоцитов. Это является одним из существенных компонентов усиления общей резистентности организма к различным неблагоприятным воздействиям (Сотникова Е. П. и др., 2005). Тридцатисуточное введение экстракта донника не вызывает дистрофически-некротических изменений и в других важнейших органах - сердце, легких, почках (Фесюнова Г. С. и др., 2006).

На модели токсического поражения печени 60 крыс четыреххлористым углеродом установлено гепатозащитное действие экстракта донника. Профилактическое введение препарата выявило антицитолитический эффект, на что указывает снижение активности трансаминаз в 1,3 раза и выраженную антиоксидантную активность - снижение диеновых конъюгатов в 1,8 раза и малонового диальдегида в 1,5 раза относительно контрольной патологии. Лечебно-профилактическое введение данного средства устраняет токсическое влияние $\mathrm{CCl}_{4}$ на печень и повышает ее физиологические возможности (Фесюнова Г. С., 2007, 2008). Такие гепатопротекторные свойства у экстракта донника выражены в большей мере, чем у другого известного тканевого препарата -ФиБСа (Сотнікова О. П. та ін., 2006). Предположительно это связано с влиянием фенольных соединений экстракта донника как ингибиторов свободнорадикальных реакций, что приводит к мембраностабилизирующему эффекту при токсических воздействиях (Сотникова Е. П. и др.,
2005). Важно, что экстракт донника помимо антитоксического действия обладает и антигипоксическим (Соколова Б. Н. и др., 2005, 2006).

При моделировании гифемы у кроликов (Фесюнова Г. С., 2007, 2008) применение подкожного и подконъюнктивального введения экстракта донника повышает фибринолитический потенциал слезной жидкости, нормализует ее коагуляционную активность и снижает внутриглазное давление на 1,8-2,3 мм рт ст. на 5 и 9 дни эксперимента, что позволяет на 5-6 дней сократить сроки рассасывания кровоизлияния в передней камере глаза в сравнении с контролем.

Мареполимиэл. Мареполимиэл-натуральный полимикроэлементный препарат на основе концентрата морской воды, содержащий комплекс органических соединений и 17 природных физиологически активных микроэлементов (алюминий, бром, железо, йод, калий, кальций, кобальт, литий, магний, марганец, медь, молибден, натрий, никель, титан, хром, цинк). Он оказывает активирующее влияние на метаболические и регенеративные процессы, является неспецифическим иммуномодулятором, а также обладает выраженными защитными свойствами при кислородном голодании и воздействии на организм некоторых токсических веществ, например ингибитора гликолиза монобромацетата (Иванийчук Т. Ю. и др., 1998, 1999, Иванийчук Т. Ю., Плевинскис В. П., 1998, 2000). Мареполимиэл не обладает тератогенными и эмбриотоксическими свойствами, не влияет на плодовитость и потомство животных (Соколова Б. Н., Шерина Н. М., 2003).

Препарат обеспечивает защитное действие при повреждении сетчатки монобромацетатом, усиливает процессы ее восстановления, на что указывает стимуляция им синтетического аппарата клеток сетчатки и появление в них нового анаболического типа белкового метаболизма. Об этом свидетельствует повышение содержания РНК, суммарных белков, аминокислот цистеина и цистина во всех микроструктурах сетчатки (Сотникова Е. П. и др., 1995). Кроме того, как показало подкожное введение мареполимиэла 57 крысам, препарат обеспечивает довольно длительный эффект такого повышения уровня перечисленных химических веществ в ганглиозных клетках и фоторецепторах сетчатки, причем продолжительность его действия практически вдвое превосходит аналогичную способность цистеина, а именно 10-12 суток против 5-7 суток (Сотникова Е. П.и др., 1996). Положительное действие биогенного препарата мареполимиэла, по-видимому связано, в частности, с улучшением микроэлементного обеспечения организма, а микроэлементы, в свою очередь, являются активаторами многих энзиматических систем (Иванийчук Т. Ю. и др., 1999). Мареполимиэл не оказывает токсического действия на культуру 
клеток почки эмбриона человека, не вызывает деструкции монослоя и морфологических изменений таких клеток, стимулируя их митотическую активность. Все приведенные выше данные позволили авторам обосновать возможность применения данного препарата при комплексном лечении дистрофий сетчатки (Салдан В. Й., 2005, Сотникова Е. П. и др., 2006) и иной патологии глаза.

Действительно, мареполимиэл оказался весьма полезным при лечении центральной дистрофии сетчатки (Савко В. В. и др., 1996). Оказалось, что даже его применение в качестве монотерапевтического средства при ее неэкссудативной форме у 21 пациента способствовало повышению у них остроты зрения на $(12,0 \pm 001) \%$. Но еще более выраженное улучшение функционального состояния органа зрения было достигнуто в группе пациентов, получавших комплексное лечение этим препаратом и витаминными, сосудорасширяющими и дедистрофическими средствами. В этом случае острота зрения по окончании двадцатидневного курса лечения повысилась на $(20,0 \pm 0,01) \%$ при уменьшении абсолютных скотом, часть из которых перешла в относительные. Препарат у таких пациентов применяли подкожно ежедневно по 2 мл в течение 20 дней и парабульбарно по 0,3 мл через день в течение 12 дней.

Е. В. Ивановская и др., $(2008,2009)$ применили мареполимиэл в составе комплексной глазной мази, содержащей кроме этого полимикроэлементный препарата декаметоксин, дексаметазон, витамины С и E, у 85 больных с первичной и вторичной дистрофиями роговицы, буллезной кератопатией, эпителиопатией. Применение ее способствовало более быстрой регенерации переднего эпителия, купированию воспалительного процесса в роговой оболочке (8,5 $\pm 5,9$ дня) по сравнению с 23 контрольными больными, получавшими желе солкосерила $(13,8 \pm 8,2$ дня). Равным образом, положительный эффект мареполимиэла, но уже в виде инстилляций препарата по одной капле трижды в день зафиксировала Н. В. Коновалова (2007). Ею этот препарат был применен в комплексной терапии передних туберкулезноаллергических увеитов у 28 больных, причем все пациенты получали интенсивную специфическую и противовоспалительную терапию и электрофорез препарата «Индоколлир». Такое лечение способствовало затуханию воспалительного процесса в сосудистом тракте глаза на 3-5 день и повышало его эффективность на 34,1 \%. Продолжая это исследование, Н. В. Коновалова и др. (2010) показали, что у 73 больных (106 глаз) с диссеминированным хориоретинитом, очаговым хориоретинитом , милиарным хориоретинитом использование электрофореза мареполимиэла в сочетании с комплексной специфической терапией оказывает нормализующее действие на Т-клеточную систему иммунитета, сопровождающееся выраженным клиническим эффектом, и по- зволяет повысить эффективность лечения на 17 \%. К сказанному о мареполимиэле можно добавить, что этот столь богатый микроэлементами биологически активный препарат при его применении совместно с химиопрепаратами у больных с впервые выявленным туберкулезом легких, нормализует иммунологические показатели, уровень биометаллов в сыворотке крови и повышает эффективность их лечения (Бабурина О. А., 1998).

Биопелоиды. Активизирующее обмен веществ влияние лечебных грязей известно давно, но лечебное действие входящих в их состав пелоидов при патологии глаз впервые было изучено Н. С. Мальте, (1969). В результате экспериментальноклинических исследований ею было установлено, что грязевые аппликации активизируют обмен веществ и повышают проникновение лекарств, которые вводятся в конъюнктивальную полость, оживляют процессы рассасывания фибрина, рубцов и инфильтратов роговицы. Достаточно подробное изложение современных представлений о происхождении, составе, теплофизических свойствах, бактерицидном действии, микрофлоре пелоидов, особенностях механизма их действия на организм, роли температурного фактора при пелоидотерапии, а также о показаниях к применению в медицине, включая офтальмологию, представлено в обзоpe В. Н. Саковича (2002). Лечебные грязи усиливают диффузные процессы и активный транспорт веществ, благодаря увеличению проницаемости клеточных мембран, ускоряют метаболизм лекарств, повышают активность ферментов. Пелоидотерапия обладает иммунореабилитационными возможностями. Сероводород пелоидов оказывает существенное влияние на уровень тканевого дыхания (Ватченко А. А. и др., 2000). А по данным О. А. Перетягина и др. (2010) инстилляции биопелоидов кроликам способствуют усилению у них миотического эффекта пилокарпина, что позволяет предполагать целесообразность их клинической апробации для лечения глаукомы, нарушений трофики глаза, непроходимости сосудов сетчатки, атрофии зрительного нерва и гемофтальмов.

П. М. Карповым (1993) доказано положительное влияние процедур с использованием сакской грязи в сочетании с переменным магнитным полем и ультразвуковым воздействием в лечении детей, страдающих ревматоидным увеитом в стадии ремиссии, а также отмечено влияние такого лечения на улучшение показателей общего иммунитета. М. В. Дунаева (1996) показала клиническую эффективность применения грязевых аппликаций озера Соленый лиман (Днепропетровская область) в сочетании с электрофорезом лидазы и алоэ в лечении помутнений и рубцов роговицы. Под влиянием проводимого лечения происходило ускорение рассасывания роговичных помутнений, повышались 
зрительные функции, активизировался метаболизм коллагена, нормализовался нарушенный общий и местный иммунитет. Лечебные грязи, содержащие БАВ, в сочетании с физиотерапевтическими методами (электрофорез, ультразвук) были применены в комплексном лечении больных с последствиями травм и хирургических вмешательств А. А. Ватченко и др. (1998, 1998-а, 2000). Оказалось, что такое лечение весьма успешно может применяться для снятия явлений воспаления через 7-10 дней после травмы или операции, для рассасывания рубцов и помутнений роговицы, рассасывания хрусталиковых масс, отложений фибрина и пигмента на передней поверхности хрусталика или интраокулярной линзы, возможных в таких ситуациях. Отмечено стимулирующее влияние грязевых процедур на процесс репаративной регенерации, что способствует более тонкому и нежному рубцеванию. При посттравматических гифемах и гемофтальмах отмечалось уменьшение имбибирования роговицы элементами крови и организации фибрина, что ускоряло просветление стекловидного тела и способствовало повышению остроты зрения.

Позднее А. О. Ватченко и др. (2003) показали, что при старых помутнениях роговицы грязевые аппликации в сочетании с электрофорезом лидазы (54 глаза) и алоэ (46 глаз) более эффективны, чем самостоятельный электрофорез (контроль). Оказалось, что в основной группе острота зрения повысилась на 0,19-0,22 (0,12 в контроле), а роговичный астигматизм уменьшился на 1,1 диоптрии $(0,7$ в контроле). Равным образом, пелоиды, содержащие биологически активные, антибиотико-, гормонои витаминоподобные вещества, оказались весьма полезны при лечении герпетических древовидных кератитов (Ватченко А. А., Сакович В. Н., 2003). При проведении комплексного лечения таким пациентам ежедневно на веки больного глаза через марлевую прокладку накладывали слой лечебной грязи, 10-15 процедур на курс. В группе больных, где применялось такое лечение, наблюдалось более быстрое рассасывание остаточных инфильтратов роговицы, раньше стихали явления воспаления, сроки пребывания на больничной койке сокращались на 3,4 койкодня. В основной группе после проведенного лечения острота зрения повысилась на 0,49, в то время как в контрольной-на 0,23.

Изучение лечебной эффективности биопелоидов продолжилось на модели травматического кератита у кроликов (Сотникова Е. П. и др., 2010), которым инстиллировали биопелоид из отгона лиманной грязи. Было найдено, что лечебные инстилляции биопелоидов при травматическом кератите оказывают выраженное противовоспалительное, противоотечное действие, предотвращают развитие грубых помутнений роговицы, на 4,5-5 суток ускоряют процессы регенерации роговицы по срав- нению с контролем. Они способствуют нормализации окислительно-восстановительной системы глютатиона в роговице, что подтверждается положительной динамикой течения воспалительного процесса. Этим и можно объяснить успешное применение пелоидов в лечении травматических кератитов. К тому же, по данным Г. С. Фесюновой и др. (2010, 2010-а), при моделированном травматическом кератите инстилляции биопелоидов приводят к снижению до исходного уровня активности таких ферментов, как лактатдегидрогеназа, каталаза, щелочная и кислая фосфатазы в слезной жидкости, что способствует ускорению репаративных процессов в роговице. Интересно, что новая лекарственная форма отгона лиманной грязи - глазные капли пелонат- является наиболее эффективным стимулятором регенерации эпителия роговицы, причем его сочетание с пиридоксином или рибофлавином оказывает менее выраженный лечебный эффект после травмирования роговой оболочки (Лотош Т. Д., Соколова Б. Н., 2008).

По мнению Г. В. Котлубей (1998), пелоидодистиллят в составе комплексного лечения показан как при стабилизации глаукоматозного процесса, так и при ее отсутствии, поскольку способствует улучшению процессов обмена и трофики тканей, уменьшению дефицита кровоснабжения. С этой точкой зрения согласны Н. И. Мартинек др. (1998), но они считают, что этот препарат в данном случае уступает по эффективности ФиБСу.

ФиБС. Одним из старейших препаратов тканевой терапии является ФиБС, представляющий собой продукт отгона лиманной грязи, в состав которого входят синтетические кумарин и коричная кислота (Фесюнова Г. С., 2008). Источник его происхождения и позволяет относить его к пелоидам. Для лечения одного из осложнений экстракции катаракты с имплантацией ИОЛ - буллезной кератопатии II-III стадии - Я. С. Чипко, Я. Г. Олейник (2003) с успехом применили мягкие контактные линзы, пропитанные препаратом ФиБС и алоэ. Это позволило через 6-9 месяцев на 5 из 9 глаз добиться полного исчезновения булл. А А. А. Юмашева, Л. М. Рудзинский (2003) при лечении проникающих ранений глаза и его контузий с помощью алоэ, стекловидного тела и ФиБСа предпочтение отдали последнему. На 274 больных они наблюдали ускорение рассасывания крови, затухание воспалительного процесса в глазу и повышение остроты зрения, чем и подтвердили данные более ранней публикации О. Р. Качмарика, О. Грицишина (1998). Равным образом, при комплексной терапии увеитов различной этиологии для иммунокоррекции первенство из тканевых препаратов разных групп С. И. Ткачев и др. (1998) также отдают ФиБСу. Т. Н. Шпак (1983) наблюдала положительный эффект от применения этого же средства, как и экстракта алоэ, при лече- 
нии различных форм герпетического кератита и аденовирусных кератоконъюнктивитов.

Подкожные инъекции ФиБСа по 1,0 мл, 20 введений на курс в сочетании с парабульбарным введением торфота Н. А. Гончарова и др. (2003) считают полезным при комплексном лечении хронических сосудистых оптических нейропатий, а Н. Д. Гаприндашвили, А. Т. Алексидзе (1998) наблюдали высокую эффективность комплексного применения антиоксидантов и ФиБСа при лечении первичной открытоугольной глаукомы, чем, по сути, подтвердили более ранние исследования Т. В. Бирич, Т. А. Бирич (1986) у 380 больных с тем же диагнозом. Впрочем, еще в 1983 году Л. Т. Кашинцева и др. отмечали, что из имеющихся тканевых препаратов ФиБС наиболее предпочтителен при лечении больных глаукомой.

Положительно оценивают результаты применения ФиБСа при комплексном лечении диабетической ретинопатии Л. Т. Кашинцева и др. (1983), а у больных сахарным диабетом с гнойнонекротическими осложнениями - И. И. Зеленый и др. (1998). П. С. Олешко и др. (1998) рекомендуют дополнить традиционное лечение тромботических поражений сосудов сетчатки комплексом из ФиБСа и антиоксиданта тиотриазолина. Этот же комплекс при лечении диабетической ретинопатии способствовал стабилизации патологического процесса в сетчатке, улучшению зрительных функций и электрофизиологических показателей органа зрения (Петруня А. М. и др., 1998). Интересно, что ФиБС, как и алоэ, проявляет синергизм действия с препаратами тимуса (тимоптин, тимоген, т-активин), благодаря чему достигается более адекватная коррекция нарушений клеточного иммунитета и улучшаются клинические показатели эффективности лечения при осложненных формах увеита (Панченко Н. В. и др., 2003).

Н. Н. Бушуева (1986) установила, что при лечении осложненной прогрессирующей миопии к использованию тканевых препаратов следует подходить дифференцированно и, учитывая антикоагуляционные свойства ФиБСа, его лучше назначать при лечении кровоизлияний в стекловидном теле и хориоретинальном слое.

Экстракт и взвесь плаценты. В завершение обзора необходимо сказать и еще об одном из старейших тканевых препаратов, вернее нескольких из них, но имеющих один источник происхождения - плаценту. Несмотря на введение в ряде стран ограничений на использование препаратов из плаценты, они продолжают широко использоваться в медицинской практике, включая офтальмологическую (Чеботарев Д. Ф. и др., 2003). По этим данным, пятилетнее лечение людей пожилого возраста взвесью или экстрактом плаценты, помимо благотворного эффекта на функцию ряда важнейших органов, позволяло сохранить на нормальном уровне остроту зрения и объем аккомодации. Согласно данным многих авторов, применение препаратов плацентарной ткани весьма эффективно в составе комплексной терапии при лечении глазной патологии, в том числе кератоконуса (Петросянц Е. А., 1956), начальных стадий синдрома Сьогрена, буллезной кератопатии (Білоус В. Й., 1998, 2003а,б), глаукомы и дегенеративных изменений сетчатки (Фролов В. М. и др., 1998), герпетических кератитов (Жабоедов Г. Д., Петренко О. В., 2003), дистрофий роговицы (Голубов К. Э. и др., 1998), постконтузионных хориоретинальных дистрофий (Безуглый Б. С., Безуглый М. Б., 1998), рецидивирующих эрозий роговицы (Жабоєдов Г. Д. та ін., 2003), частичной атрофии зрительного нерва (Иваницкая Е. В. и др., 2005). Поскольку было установлено положительное влияние взвеси плаценты, а также ФиБСа на нарушенное кровоснабжение глаза у больных сахарным диабетом при ангиопатии сетчатки, то Л. В. Козина (1984) рекомендует их применение у таких лиц с целью предупреждения развития диабетической ретинопатии. АЛ. Т. Кашинцева и др. (1983), В. И. Белоус (1983) отмечают положительный эффект от включения экстракта или взвеси плаценты в комплексное лечение уже имеющейся диабетической ретинопатии.

Свежая послеродовая плацента, консервированная по методу В. П. Филатова, достаточно активна при ее имплантации благодаря высокому содержанию ряда биологически активных веществ и способности повышать реактивность организма, стимулировать метаболизм и улучшать процессы его регуляции. Этим и обусловлено ее широкое применение при хирургических, дерматовенерологических, терапевтических, неврологических заболеваниях, а также в андрологии, сексопатологии, психиатрии, урологии, акушерстве-гинекологии и прочих медицинских дисциплинах (Кукурикин Ю. В., Рачкаускас Г. С., 2003). Плацента широко используется в виде экстракта, гомогената, фрагментов ткани, причем передовые биотехнологии - низкотемпературное консервирование, лиофильная сушка позволяют сохранить в материале биологически активные вещества - ферменты, гормоны, ростовые факторы. Среди них тестостерон, альфа-фетопротеин, лактоферин, хорионический гонадотропин, пролактин, тестостерон, прогестерон, соматотропный гормон, такие цитокины как G-CSF, TNFa, IL-4, IL-6, IL-1 (Юрченко T. H. и др., 2003).

\section{ЛИТЕРАТУРА}

Bсе публикации, процитированные в настоящем сообщении, приведены в списке работ к его первой части (Офтальмологический журнал № 3, 2011 г.). 